\title{
Family-based Social Activism: Rethinking the Social Role of Families
}

\author{
Dr. Norine Verberg St. Francis Xavier University
}

\begin{abstract}
Résumé
Le présent article éclaire l'activisme social familial défini comme suit : toute la gamme d'activités entreprises par les membres d'une famille pour sensibiliser l'opinion ou amener un changement de politique, au vu d'un état grave ou d'un événement tragique frappant ou ayant frappé une personne de cette famille. Ces activités constituent de l'activisme social parce qu'elles visent à promouvoir un changement social. L'activisme est « familial » parce que la personne militant pour un changement social est un membre de la famille qui réagit à une situation grave ou traumatique affectant ou ayant affecté un membre de cette famille. Citons, parmi les nombreux groupes militants familiaux s'étant constitués au Canada : Mothers Against Drunk Driving, Westray Families Group et Family and Friends of Schizophrenics. Le militantisme familial ne fait pas l'objet d'études spécifiques dans les écrits de sociologie consacrés à la famille, aux mouvements sociaux, aux problèmes sociaux ou aux membres d'associations bénévoles. Le premier but du présent article est donc de cerner la question du militantisme familial et de fournir des preuves empiriques de l'étendue du phénomène au Canada. Son second but est de positionner le militantisme familial dans les écrits de sociologie, en avançant des théories inspirées par la sociologie de la mémoire sociale et en suggérant diverses possibilités d'élaboration de théories dans le cadre de l'étude des familles.
\end{abstract}

\begin{abstract}
This paper sheds light on family-based social activism, defined herein as the broad range of activities undertaken by family members to raise awareness and bring about policy reform about a serious condition or tragic event that affects or affected someone in their family. These activities constitute social activism because they are intended to foster social change. The activism is 'family-based' because the social change advocate is a family member responding to the serious or traumatic situation that affects or affected a family member. Mothers Against Drunk Driving, the Westray Families Group, and Family and Friends of Schizophrenics are just a few examples of the many family-based social activist groups which have formed in Canada. Family-based activism is not addressed as a specific subject of study in the sociology literature on families, social movements, social problems, or voluntary association membership. The first goal of this paper is to bring family-based social activism into focus and provide some empirical evidence of this phenomenon in Canada. The second goal is to situate family activism in the sociology literature by drawing theoretical inspirations from social memory literature and suggesting avenues for theoretical development in perspectives on families.
\end{abstract}




\section{Introduction*}

This paper sheds light on family-based social activism, a form of social action that appears to have escaped the attention of sociologists. The term family-based social activism refers to the broad range of activities undertaken by family members to raise awareness and bring about policy reform about a serious condition or tragic event that affects or has affected someone in their family. These activities constitute social activism because they are intended quite explicitly to bring about social change. The activism is family-based in that the social change advocate is a family member acting in response to a serious or traumatic situation involving a family member. A broad range of experiences and circumstances motivate family members to become activists, and family activists define for themselves a broad range of goals. Some family members work to achieve legislative or policy reform related to a tragedy or an injustice that caused death or bodily harm to a family member. Some family members lobby for better services or greater access to health care for a family member with special needs or a chronic illness. Some families raise money for research into the cure or management of chronic disease. Some family members work alone to raise awareness, while others work through formal organizations they establish or join to influence attitudes and affect change. Although this paper gives somewhat greater attention to family activism which addresses tragic death and social injustice, it is important to remember that the scope of family-based activism is quite broad.

Family-based activism is not addressed as a subject of study in the sociology literature on families (see, for example, Ingoldsby, Smith \& Miller, 2004; White \& Klein, 2002), social movements (e.g. Snow, et al., 2004), or voluntary association membership (e.g. Bussell \& Forbes, 2001; Curtis, Baer and Grabb, 2001; Rotolo, 1999). Thus, the first goal of this paper is to bring family-based social activism into focus and provide some empirical evidence of this phenomenon in Canada. I contend that family-based social activism is far more common than the sociological literature would suggest, and I provide some preliminary comments about the nature and scope of such activities. The second goal of the paper is to contribute to the development of a conceptual framework for the analysis of family-based activism, and I draw on social memory literature to do so. Bringing family-based activism into focus in this way will hopefully highlight the need to revisit much of the theory and research conducted on families, and also on social change, social movements, and voluntary associations. This particular paper is a step in that direction.

\footnotetext{
* An earlier version was presented at the Annual Congress (Canadian Sociology and Anthropology Association), London, Ontario, June 1, 2005. I acknowledge the funding support provided by the Centre for Regional Studies and the University Council for Research at St. Francis Xavier University, and the HRDC Student Employment program. I thank Caitlin Mulcahy for her excellent work as my research assistant. I am grateful for the helpful comments from two anonymous reviewers. Special thanks to Patricia Cormack and Yvon Grenier for valuable comments on an earlier draft. Contact: nverberg@stfx.ca
} 


\section{Methodology: Measuring Family-based Social Activism}

In my view, family-based social activism is a much more commonplace activity in contemporary Canadian society than is recognized by sociology. I would suggest that the reasons it has escaped notice in sociology may also serve to explain why family-based activism is also difficult to measure. When I began to recognize family activism as possibly a patterned type of social response to situations faced by families, I started a file in which I placed newspaper clippings, event posters, and field notes on events or activities that I considered examples of family-based social activism. The inclusion of field notes in my file served to document events or activities not documented in print media or announced on poster boards (e.g. events announced on television or radio programs or learned of through everyday interactions). As haphazard as this may seem, this process allowed me to document hundreds of activities that would otherwise never have been pulled together to form a database. Because there is no blueprint for activists to use, family members employ a variety of means for delivering their message. I have one or more documented cases of the following types of activities: giving one lecture at a local high school or a lecture series in high schools across the country, entering a float in a parade, organizing a memorial golf tournament, holding an annual memorial stock car rally, cycling across the country for a cause, starting a chapter of an established charitable organization, founding a new social change organization, going door-to-door raising funds for a cause, taking part in one or more fund-raising events related to the issue, establishing a website, and so on. Events or activities such as these are sometimes reported in local or national newspapers or televised on news programs, yet most smaller-scale actions are only ever announced on community bulletin boards, school newsletters, or community bulletins. On the whole then, it is unlikely that the activities that constitute family activism could ever be documented in any sort of systematic or consistent manner. This being said, it is still possible to find information about a great number of cases, enough of them, arguably, to identify some patterns and draw theoretical lessons for the sociology of family and social change.

I expanded my sample of cases of family-based social activism by using library and webbased search engines. Searching Canadian newspapers seemed an obvious way to go given the numerous examples of family-based activism reported in those newspapers and magazines I read on a regular basis. It was my research involving the Westray Families Group that first drew my attention to the appeal of the Internet for social change advocates. The Westray Families Group was formed by the families of coal miners killed in the notorious Westray mine explosion (Plymouth, Nova Scotia, 1992) to address the criminal aspects of the explosion. Thirteen years later, this group continues to influence public opinion on workplace safety and corporate responsibility for the safety workers. As a small group of families holding jobs and raising children, they had little time and few financial resources to draw upon to develop their activist voice. Among their other strategies, they 
developed, and continue to maintain, a website as an activist tool (Verberg and Davis, 2004). Indeed, other writers have noted that an Internet site is a potentially powerful resource accessible to even those with limited financial resources (see, for example, Roper, 2002; Warf \& Grimes, 1997).

To begin my media and web searches, I used the newspaper articles I had clipped over the past few years to select key words. Many of these articles tell a personal story about a "preventable" "tragedy" that launched a "family" member into an activist role. Thus, the terms ${ }^{1}$ family, tragedy and prevention were used to frame my respective library-based searches. I later expanded my search by substituting the term "family/families" for "mother" "mom" "father" "parent", etc, and I used various other terms related to activism, including "against" (given the familiarity of Mothers Against Drunk Driving) to find relevant newspaper articles or family-based activist sites.

Although we stand to learn a great deal about family activism from newspaper reports and activist websites, relying on this database alone would leave many important questions unanswered. My analysis also draws upon interview data collected through case studies I developed on the Westray Families Group ${ }^{2}$ and, more recently, Mothers Against Drunk Driving and Fondation Six Décembre (described below).

In this paper, I strive to illuminate the broad range of public activities that families do with the specific intention of raising awareness and/or advocating policy change to prevent tragedies or tackle concerns or problems facing families. From these sources, we can begin to identify the issues which pull families together to work toward making real and lasting social change, the strategies family activists use to achieve their goals and, the individuals and groups with whom they forge coalitions. We also stand to learn a great deal about social relations, the media, and the role of families in the societies in which family-based social activism emerges.

\section{Characteristics of Family-based Social Activism}

The goal of this section is to sketch out some of the characteristics of family-based social activism. Attention is given to the range of individual and group activities family activists initiate. I distinguish between short-term, smaller-scale activities and longer-term, more formally organized responses, noting that both constitute forms of family-based activism. I point to some of the social issues raised by families, and in doing so provide examples of family-based social change organizations. To begin, consider three examples of family activism drawn from Canadian newspapers.

1 The truncated terms famil*, prevent*, and trag* were employed where possible. 
1) One front page headline reads: "The hidden perils of bed sharing: Exhausted from childbirth, Miranda Halladay took a nap with her healthy new son. When she awoke three hours later, he didn't." The journalist notes that "Ms. Halladay decided to tell her story.... to warn of the dangers of bed-sharing with young children." In her words, "We want everyone to learn from our horrible experience, so no one else will have to suffer from a preventable tragedy."... "If we save just one baby by telling our story, that will keep Rex's memory alive." (emphasis added) [Globe and Mail, July 19, 2003, A1]

2) Following the headline "Deep waters run still" we learn that an aspiring young man named Peter Crompton died when he was hit by a motor boat operated by an impaired driver. The journalist tells us that "Ken Crompton (Pete's father) made Pete's memory his mission. He arranged for the construction of a 29-ton stone marker known as an inukshuk at Sunset Point, where Pete learned to windsurf. He set up a Peter Crompton ski day, with proceeds going to Snowsmart and Smartrisk-organizations dedicated to the management of risk and the prevention of accidents. Since his son's death, Mr. Crompton "has lobbied for improvements to boating safety legislation" saying that "If I could believe that just one person lived because of him, that would make a big difference." (emphasis added) [Globe and Mail, July 31, 2004, F1-F2]

3) Another headline reads "Concert puts victims in spotlight: Family of slain teen use music to understand the cycle of violence". This article reports on an event called Change the Tune: Taking Action Against Violence in our Community. Yancy Meyer was murdered by a poor young man who attempted to rob the convenience store where Yancy worked. The event was organized by Yancy Meyer's parents ${ }^{3}$, Matthew Meyer, a drama professor, and Louise Meyer, a ballerina "to remember victims of violence while drawing attention to the need for preventative measures to avert such brutal acts." The Meyer family suggests that such 'affirmative action' could include a youth centre in the town where users could benefit from constructive programs, and enhancing the resources of social services to prevent people such as his son's killer, from "falling through the cracks." Louise Meyer said that "it takes tragedy to bring people together and tragedy to make people move. When it happens to you, you feel compelled to do something." (emphasis added) [Halifax Chronicle-Herald, December 8, 2003, A7]

A number of common themes run through these newspaper articles. First, the activists selfidentify as the 'family' of victims of a 'preventable' death. In these cases, the activists are

\footnotetext{
${ }^{3}$ Six months later another newspaper reported that the Meyer family established a bursary at St. Francis Xavier University. Mr Meyer said “This bursary honours Yancy's memory in a way that will benefit future students at St. F.X. We can find some solace in the fact that this horrible tragedy will benefit students who have to work to support their studies, as Yancy did." The article concluded by saying that the Meyers remind us "that preventing violence in all its forms is everyone's responsibility" (The Casket, Antigonish, Nova Scotia, June 2, 2004).
} 
parents, but my research indicates that family activists may also be the affected person's spouse, daughters, sons, siblings, grandparents, cousins, in-laws, or even more distant relatives. Second, in these cases, the family member-activists suggest that the cause of death was preventable, a view which is echoed and reinforced by the journalists in each newspaper article. Third, the family members are engaged in purposeful action intended to influence what we think and what we do, both as individuals and as a community, to save lives. They leave us both with a sense of despair and a sense of hope. Our despair is rooted in the senseless death: our hope rests with the possibility of change. Their work is both pedagogical and policy oriented. Ultimately they want to make their experience familiar to us with the hope that we will prevent similar tragedies from occurring in our families and work towards changing the conditions which led to the tragedy.

Preventable tragedies of all sorts seem to provide a spark for family members to engage in social activism. The examples cited above draw our attention to three tragic deaths that could have been prevented. Indeed, tragic death can bring families to activism, but in our conceptualization of family-based activism, we must take note of the many family activists striving to prevent tragedies that they have foreseen. Some people become activists because a family member has a condition that makes them vulnerable to tragic death if preventative efforts are not taken. For example, Save the Smarties was an internet-based action undertaken by the father of a child with a deadly peanut allergy. He mounted a successful internet campaign to create public pressure on the Nestlés Corporation to continue production of peanut-free candy bars. I would also include in this group the many families that promote research into the prevention, treatment, or "cure" of chronic disease, through their intermittent or sustained involvement in campaigns launched by national associations such as the Canadian Diabetes Association and the Meningitis Research Foundation of Canada. Children's Heart Society, Parents of Deaf Ontarians, and Parents of Kids with Infectious Diseases are a few examples of the numerous family-based organizations founded and run by parents to address their children's chronic disease or special needs. In amateur sports associations, parents often mount highly organized protests about perceived risks or unfair practices, such as the recent debate about whether body checking has a place in miniature hockey. These families have not experienced a preventable tragic death, but their activism is rooted in perceived risks known to be faced by individuals who share similar life circumstances.

To further our understanding of family-based activism it is important that we acknowledge that some family members engage in smaller-scale, sporadic activities that take place on the local level, while others are drawn to larger-scale, on-going activities specifically aimed at achieving longer-term structural change or policy reform. Smaller-scale activities tend to be carried out by a family member either alone or with the cooperation of family, friends and community members who share their sense of a need for change. In the 
examples noted above, Miranda Halladay worked alone giving presentations in local venues, whereas the performance event organized by the Meyers took place on one night and involved dancers, poets, musicians, and actors who wanted to help the Meyers bring the cycle of violence and the need for prevention into focus. In my database, I have numerous examples of smaller-scale local activities, including giving one or more public lectures, establishing a memorial scholarship, sponsoring a local fundraising event, or some combination of activities. Many of these small-scale types of activities seem to emerge within the first one or two years following the tragedy.

We might be tempted to disregard local, episodic actions as less important than larger-scale organized activities, surmising, wrongfully in my opinion, that local actions will have little direct or immediate impact on policy reform. I would suggest that the narratives of justice created through local interactions do affect people's attitudes and behaviour, even if in diffuse and hardly measurable ways. Speech act theorists define speech as action and they suggest that narrative performances are context dependent (Maclean, 1988). Narrative performance involves a construction of reality, the creation and involvement of an audience (e.g. storyteller, listener), and considerations of how to construct narrative authority. Narrative performances reveal a great deal about power and social relations in culture and society. Creating an audience and moving that audience to engage in the storytelling requires family member-activists to draw upon key cultural connections that are shared and meaningful to the people they target. Making cultural connections may be easier at the local level, where face-to-face interactions bring forth constant reminders of the circumstances surrounding the loss or the concerns faced by family activists. And being known in the community can influence achieving narrative authority. Creating and maintaining an audience and gaining narrative authority beyond the local level of interaction poses different challenges to family-activists. I return to this idea later, after describing family-based social change organizations.

Family activists who initiated small-scale, short-term projects sometimes become involved in longer-term, more formally organized responses. Many families create or join a formal organization dedicated to bringing about changes in the targeted area. Mothers Against Drunk Driving is perhaps the most familiar family-based social change organization in Canada; numerous others are introduced below. Like many family-based social change organizations, MADD is registered as a charitable, non-profit society guided by a board of directors, by-laws, and terms of reference. By organizing, family activists can more effectively bring together various resources and coordinate their efforts. John Kenneth Galbraith argued that modern times can be characterized as an age of organization (1983:131). Within sociology, social organization has received considerable attention, yet families that employ organizational models in the pursuit of a common social objective have yet to be studied in a systematic way. 
Based on my database, I can offer some preliminary observations on the characteristics of family-based social change organizations. First, the membership of the family-based social change organizations, or at least a core of it, is made up of family members fighting for change related to an event or circumstance that affects or has affected a family member. They come together with similarly affected family members who believe that their "private troubles" are "public issues". Second, they define an explicit goal of affecting policy change, which is captured in their mission statements and their activities. For example, the mission statement of the Families of September 11 states that the group's purpose is decidedly oriented to affect policy: "To promote the interests of families of victims of the September 11 attacks and support policies that improve the prevention and response to terrorism" (http://www.familiesofseptember11.org/default.aspx). The mission statement for Mothers Against Drunk Driving states emphatically that MADD Canada wants to change the way people look at impaired driving: "MADD Canada is a non-profit, grassroots organization that is committed to stopping impaired driving and supporting the victims of this violent crime. At the heart of MADD Canada is our volunteers who include not only mothers, but fathers, friends, business professionals, experts in the anti-impaired driving field and concerned citizens who want to make a difference in the fight against impaired driving" (http://www.madd.ca/). As part of my on-going research I have documented the mission statements posted on more than sixty family-based organizations' websites. Like the statements above, these mission statements typically identify two goals: they support affected families and they promote social change.

As suggested by the MADD Canada mission statement above, membership in familybased social change organizations is not limited to victims' families. Membership can encompass those directly affected as well as those who share the vision for change. This inclusive approach allows for the potential of creating larger, better-funded organizations capable of coordinating efforts and actions directed at a specific policy reform. For example, MADD Canada has 80 chapters across the country; the national organization claims to have over two million supporters, including volunteers and donors. The MADD Canada website identifies so-called "volunteer opportunities" in the following areas: chapter board member, public policy, victim support volunteer, court monitoring, public education and awareness, public speaking, fund raising, and media relations (http:www.madd.ca). MADD also indicates that its membership is comprised of victims, victims' families and "people concerned about safety in their community and having the desire to stop the deaths and injuries caused by impaired driving." Many family-based social change organizations in my database use this strategy of expanding membership to include people who share the families' vision of change.

My research suggests that becoming organized to affect longer-term change is an increasingly common familial response to a family tragedy or situations which might be 
described as a family challenge. Further research is required to assess the validity of this claim. In the meantime, the remainder of this section provides an overview of some of the types of issues that have been addressed by family-based social change organizations. Doing so gives a sense of the scope of these organizations, and provides examples of family-based social change organizations.

Like MADD, Mothers of the Disappeared is a familiar family-based social change organization, international in scope and established for decades. The 'mothers of the disappeared' movement started in Argentina with the Mothers of Plaza de Mayo who organized in response to the mass 'disappearance' of some 30,000 people, including their children, by the grossly repressive and violent military dictatorship that lasted from 1976 to 1983 (Holst-Warhaft, 2000). The disappeared people who were kidnapped, tortured and assassinated were intellectuals, political opponents, Jews - virtually thousands of men and many pregnant women who were taken from homes and public places, seemingly at random. Pregnant women who disappeared were kept alive until their babies were born; the infants were given to childless military families. The regime tortured and murdered its captives, and placed their bodies in mass graves or dropped them from helicopters into the sea. Although the campaign of terror was intended to silence opponents, the mothers of 'los desaparecidos' marched in the Plaza de Mayo in Buenes Aires, demanding the return of their children, or at least to know their fate, persevering even after some of the mothers leading the protest disappeared.

The Mothers of the Plaza de Maya protest eventually became so well known internationally that it spawned the establishment of a number of similar grassroots organizations. In Argentina, for example, Grandmothers of Plaza de Mayo was established by the grandmothers of the babies born in captivity who sought to locate and be re-united with their grandchildren. Around the world a number of organizations emerged and adopted the name Mothers of the Disappeared. My database includes documentation of Mothers of the Disappeared organizations in Guatemala, Turkey, Yugoslavia, and Iran, as well as other groups similarly named such as Desparecidos / Project Disappeared and Parents of the Disappeared. In Argentina, after a civilian government succeeded the dictatorship, The Mothers of Plaza de Mayo demanded that the government investigate the atrocities committed against their children, prosecute those who committed the human rights violations and crimes, and locate and recover the grandchildren born in captivity, among other goals (Holst-Warhaft, 2000). Their continued presence a quarter of a century since they first responded to the kidnappings suggests that these families will continue to act until they achieve justice.

Numerous examples can be found of the families of murder victims who organize to affect change. Victims' families have established organizations to raise awareness about violence 
against women, violence against children and youth, and violence against gays. Fondation Six Décembre, established by the families of the fourteen women murdered in the Montreal Massacre, and CAVEAT, founded by Priscilla DeVillier, whose daughter Nina was murdered in Ontario by a known sex offender, are two Canadian coalitions founded by victims' families. They are credited with influencing the establishment of December 6 as a National Day of Remembrance and Action on Violence Against Women, and they are among the many family-based groups lobbying for gun control legislation (other examples include Mothers Against Guns, Mothers Against Violence in America, and the Million Mom March). Chuck Cadman became a politician after his son was murdered by a young offender. He established Crime Responsibility and Youth (CRY) to address youth involvement in crime. He was elected a Member of Parliament in two consecutive federal elections on a crime prevention platform. Following the murder of their gay son, Judy and Dennis Shepard established the Matthew Shepard Foundation to lobby for hate crime legislation in the United States. The Coalition of 9/11 Families was established by the family of the victims of the terrorist attack on the World Trade Centre. This organization played a central role in the media coverage of the $9 / 11$ Commission, it influenced the plans for the 9/11 commemoration and demands consultation on the site renewal, and maintains pressure on the American government to address various issues related to terrorism and victims' rights. Numerous family-based organizations have also been founded by the families of Holocaust survivors to address a variety of post-Holocaust issues, particularly concerns about erasure and remembrance (see, for example, LaCapra, 1998; Linenthal, 2001). Many other examples can be found in Canada, the United States, and in nations around the world.

Another category of family-based social change organizations are those organizations that benefit from the routine involvement of other families affected by the issue, but which do not use the term "family" in the organization's name. For example, the Meningitis Research Foundation of Canada was established by Michael Longo's mother following his death at age twenty of meningitis. Many disease-focused organizations have extensive family support and involvement, which is highlighted on their websites. For example, in 2005, the Meningitis Research Foundation of Canada featured a fundraising campaign called Journey for Julia, in honor of Julia McCann who died at age four of meningitis. Her father, Russ McCann, cycled across Canada in the summer of 2005 to raise awareness about the disease and to raise funds for research on meningitis. Indeed, most of the organizations dedicated to supporting families and those afflicted by specific diseases do not have a family term in the organization's name (e.g. Canadian Cancer Society, Canadian Diabetes Association), yet these organizations recruit the families and individuals affected by the illness to take leadership roles in fundraising campaigns. Local and national papers routinely feature family members who take part in fundraising campaigns such as the 'walk/run for the cure' and the 'relay for life'. These organizations 
often feature the real lived experience of family members in their fundraising strategies. Other organizations invite people to make a memory gift (i.e. a donation) to commemorate a friend or loved one who died of complications related to a disorder, or to make a pledge to support the fundraising activities of the family and friends of those suffering from the disease in question. Many door-to-door canvassers are relatives of persons who have fallen ill or died of the disease. When asked to donate, we are often asked by the family member of someone affected by the disease or someone who has the disease. However anonymous that person may be, knowing that the person is a family member makes them familiar to us. Clearly, research on family-based activism ought to focus on the extent to which volunteerism in these organizations is family-based, and whether or not the public perceive that volunteers are the family members of someone afflicted by the disease. We need to include these organizations in our operational definition of family-based activism, at least until such time as we can investigate the degree to which the organization attracts, and is supported by, family activists.

That said, most family-based social change organizations do use a family signifier in the organization's name-Mothers Against Drunk Driving, Westray Families Group, Grandmothers for Peace International. The enduring social significance of the maternal role is reflected in the strong presence of mothers among these family activists, and the use of the term 'mother' in the organizations' names. When the phrase "mothers against" was used in the web search, it identified a number of mother-led websites such as: Mothers Against Meth-Amphetamines, Mothers Against Guns, Mothers Against Circumcision, and Mothers Against the Draft. Using the key words "mom" or "mother" in conjunction with other key words such as "prevention" or "victimization" produced links for still more mother-led activist groups, such as The Mothers of Plaza de Mayo, Million Mom March, and Mothers of Lost Children. Using the key words "fathers against" or "fathers/dad" with "prevention" did not yield examples of family-activist organizations, with the exceptions of two father's rights organizations: Fathers for Justice and Dads Canada, which lobby for fairness in child access and custody following divorce. This does not mean that fathers are not activists; men are clearly counted among family activists. In fact, the organization Mothers of the New York Disappeared was established by the father of a prison inmate. He and other parent activist incorporated the term Mothers of the Disappeared in their organization's name because they believe that the unduly long-term prison terms assigned by the State of New York for minor infractions represent a form of state-sponsored disappearance. Given the strategic use of the signifier "mother" by this family-based social change organization begs the question, are mothers and grandmothers more likely to be family activists, or do family-based social change organizations tend to use the term "mother" strategically when naming their organization? Clearly, this focus on mothers warrants study and consideration. 
One thing is clear, mothers are not the only family members to be involved in family-based efforts to influence attitudes or advocate policy reform. Newspaper records listed above show that a mother took the lead activist role in the first example, a father took the lead activist role in the second example and both parents worked collaboratively in the third example. A web search revealed that many family-based social change organizations use the term "families" or "parents", in their organizations' names, such as: Parents, Family, and Friends of Lesbians and Gays, Parents of the Disappeared, Family and Friends of Schizophrenics, Families of September 11th, Coalition of 9/11 Families, Westray Families Group, and Parents Against Corruption and Cover-up, to name a few of them. As these names suggest, sisters, brothers, fathers-in-law, cousins, aunts and uncles are also involved as family activists. For example, the position of President of Fondation Six Décembre has been filled twice by sisters of the victims. Likewise, leadership or regular participation in the Westray Families Group over its thirteen year life was provided by some of the wives, some of the parents, some of the brothers, a father-in-law, at least two sister-in-laws, and a cousin. Regardless of their relationship to the victims, their involvement was intense and it enacted tremendous personal costs for several years of their lives (Verberg and Davis, 2004).

There appears to be something strategic about designating an organization as a familybased organization. Family activists seem to understand that family status carries weight with the public because only a close relative can bring home the issue, so-to-speak. Family activists seem to know that it is their family connection that gives them credibility and an audience. $M A D D$ Canada actively recruits members who have not been directly affected by impaired driving, yet its by-laws specify that the president and regional managers must be a relative of a victim of impaired driving. In our information age, appeals to the personal may be an important tool which families use to broadcast their message about a policy issue that can help prevent tragedy. Family-based activists attempt to demonstrate that their "private" family experience is in fact a "public" issue. They seem to be able to accomplish this by maintaining that the political or "public" issue has relevance for our "private" lives. If we do not do something about impaired driving, for instance, people, at random, will die. Knowing their relation to the victim or affected person personalizes the issue because we can imagine how our family would be affected. In other words, even if the victim is not your family member, you understand the issue better when you imagine how it is experienced by a family.

Holst-Warhaft (2000) argues that the mothers who launched the Mothers of the Disappeared movement were able to draw international attention to the human rights atrocities taking place in Argentina because they shifted the public focus away from the tortures, the government, and even the victims, and forced us to consider their own real, personal grief. 
We have been made familiar with images of exhumation of remains in the mass graves of Guatemala and Argentina, of the mothers of the Plaza de Mayo holding pictures of their children above their heads. We know that many of the victims suffered unimaginable torture for a period before they died, but the agonizing grief of those relatives is what we focus on. The pictures of the disappeared are posed, expressionless images, taken from student identity cards, passports, studio portraits, police mug shots. It is the women beneath them, in their white headscarves, holding the pictures of their children, who become unwittingly the focus of the camera's and our attention (Holst-Warhaft, 2000: 15-16).

Indeed, the mothers transformed a news story about anonymous human rights abuses into family tragedies. The political is presented as personal, giving a human face to the atrocities affecting thousands of families. In doing so, they invite us to imagine the unimaginable. They invite us to help them.

Whether the activist is involved in a smaller-scale local activity or a larger-scale, formally organized one, her or his narrative performance rests upon shared notions of kinship. Family-based social activism appears to draw upon the notion that there is something elemental in this life that is shared; they seem to say "we may not be blood relations or partners, but we do share what it is to be family and what it is to work together as family.' When something upsets our shared notion of family, the upset is taken up with the kin. Kinship here is not narrowly defined by consanguine and conjugal relations, but is a much broader, more inclusive notion of brotherhood and sisterhood. These imaginative relations are reflected in, but broader than, concepts such as adoptive kin or fictive kin, defined as those taken to be kin because of shared sentiments, values and experiences. The notion of kinship has received short shrift in the discipline, likely owing to the causal importance given over to the nuclear or conjugal family in much sociological theorizing.

There is a limit, however, to the appeal of the family status for maintaining an audience once created, and family activists know this. Family activists learn to devise strategies to bring the issue and proposed policy changes or laws into focus. One strategy is to define the issue very clearly and make the case repeatedly. They must be skilled with the media, express their views clearly and authoritatively. As suggested by McCarthy and Edwards (2004), social capital plays a major role in the success of social change organizations. Family activists understand this. They learned how to create alliances, know where to be, when to call the press, how to respond to events that draw attention to the issue. They learn that anniversaries or key dates provide opportunities to draw media attention to the issue. For newcomers, the learning curve is great. Family activists I have interviewed note that becoming an activist is a process. Some express having been transformed from having a 
relatively passive political role prior to their loss to having become engaged as political agents, guided very specifically by a sense of purpose rooted in the tragedy that so needlessly took the life of an innocent person, a member of their family. Becoming skilled at dealing with the media (defined as getting the message out), learning strategies to bring the issue and need for change into focus, and creating coalitions are part of this transformative process.

In addition to developing strategy for getting the public's attention, family activists strive to gain legitimacy. Family activists want to change the status quo, and as such, they engage in a competition over how the problem or event is conceptualized. To gain legitimacy for their cause, family activists use two main approaches: coalition building and use of independent sources that collaborate with their position. In the article reporting Miranda Halladay's activism, the journalist reports the debate about bed sharing (i.e. infant sleeping in the parent's bed) and the statistics on infant suffocation in Canada attributed to bed sharing. The inclusion of these statistics gives credibility to Ms. Halladay's warning. Likewise, in the article on the Crompton family's activism, we learn that 200 people died in motor boat accidents involving impaired drivers every year, and on the MADD Canada website, we learn that everyday four Canadians die and an additional two hundred are injured in impaired driving accidents. The members of Fondation Six Décembre advocate for greater gun control, and they have drawn upon statistics reporting a considerable reduction in gun deaths since the introduction of the controversial gun registry to bolster their position. They do so because they are well aware of groups that lobby against their position. For example, Fondation members are acutely aware of the influence of Canadian gun lobbyists, who they believed receive funding from powerful organizations such as the (American) National Rifle Association. What is common is that family activists seek to gain legitimacy ${ }^{4}$ for their position by establishing coalitions and using independent reports (e.g. public inquiry reports, official statistics, medical opinion, etc).

\section{The Paucity of Literature on Family-based Social Activism}

The direction family theories might provide for understanding family-based social activism requires the attention of a full article. Nonetheless, it is worth noting that there is a paucity of theory or research that is directly focused on family activism. Moreover, with the exceptions of feminist, systems, and ecological theories of families, little attention is given to what families do in the world (See, for example, Boss, 1993; Burr, 1979; Cheal,

\footnotetext{
${ }^{4}$ The detractors may be other family activists who stand on very different sides of an issue. One example of this is the family activism around mandatory childhood vaccinations (e.g. Stop Chicken Pox, Parents of Kids with Infectious Diseases). Some families are strong proponents of childhood vaccinations (i.e. they became advocates because they believe that their child's death or disability could have been prevented by a vaccine); others stand opposed to vaccines (i.e. they became antivaccine activists when their child became gravely ill or developed autism, which they believe was caused by childhood vaccinations). As with other groups, these organizations strive to gain legitimacy by referring to outside sources for 'factual information' considered valid by the public (official statistics, medical opinion, etc.)
} 
1991; Elshtain, 1982; Ingoldsby, et al., 2004; Sprey, 1990; White and Klein, 2002). Traditional theorizing on families tends to be more narrowly focused on the internal aspects of families (i.e., family relationships, family violence, conjugal power, divorce) or the role parents play as the primary agents of child socialization. As for the role of families in society, there has been a clear tendency to associate families with "tradition," stability, order, system reproduction, system maintenance, and so on. Until the 1960s, theories tend to describe families as promoting conservative attitudes and behaviours, not social criticism and social activism. Families are seen to influence society through their behaviour within the private sphere of the family home, such as when parents teach children to internalize societal values. These perspectives leave little room for integrating family based activism. Given the focus on family roles by some of the traditional approaches, the actions of those family members who act to ensure there is adequate care and infrastructure in place to protect vulnerable or ill family members might be treated as a 'natural' extension of family roles: providing care and security to family members. But what of those who become involved in family-based activism following the tragic, preventable death of a loved one? In these cases, it seems unlikely that the outcome of their activism will directly affect their own family. The drunk driver who killed your father may drive again or the man who gunned down your daughter may have taken his own life. Nothing can turn back the clock. What remains possible is changing the circumstances associated with the tragic loss. The family member becomes involved in prevention activism to save other innocent people from death or bodily harm. This is certainly a noble pursuit, but does it belong in the study of family and family life? Should we see the former type of activism as family activism, and the latter of another sort? After all, the work is done outside of the privacy of one's home and the end result will not alter the family loss that has taken place. In fact, it may well draw one away from family life, and into public life. If we accept the private/public dichotomy implicit in much of the traditional theorizing on families, we might well conclude that such activities should not concern family sociologists.

If we take the position that all these types of family-based social actions and organizations attest to the interconnectedness of families to each other and to other social institutions, then family activism might provide a fruitful area of research to develop theories focused on the way families influence the broader society. Since the 1960 s, critical perspectives on families have explored how families influence the broader social system. Feminists have certainly challenged the traditional conception of the family as an imminently "private" institution whose sole social relevance is its entrenched capacity to safeguard traditions and reproduce the existing social order, and they have shown how families are interconnected to other social institutions (ie. Maroney and Luxton, 1997). Some contemporary theories, such as systems theory and ecological theory, propose "meso" level interactions between families and other social institutions (Sprey, 1990). Although 
feminism and ecology theory may prove fruitful avenues for developing theory on familybased social activism, the activities referred to in this article have not been discussed by family theorists to date, nor have they been the subject of any investigation I am aware of by family researchers.

I explored the literature across a wide spectrum of subjects and disciplines to find studies focused on family activism. I have already cited Gail Holst-Warhaft's (2000) discussion of the Mothers of the Disappeared movement in her book, The Cue for Passion: The Political Uses of Grief. She argues that grief is a potent catalyst for activism, yet she does not give special attention to 'family' activism per se. In fact, she refers to Mothers of the Disappeared as a "political grassroots organization". When she focuses on the activism within the "gay community" around the AIDS epidemic, she mentions the "relatives" of gays in passing, but she does not analyze the role played by the parents and partners of gays. In the chapter on the tragic death of Princess Diana of Wales, she focuses exclusively on the grief and activism of Diana's "fans".

I found only three other publications focused on family-based activism: a magazine article and two journal articles. In 1994, a short piece appeared in Today's Parent Magazine focused on a few parents who lobbied to have programs and policies developed that will help children with various special needs, disabilities, or health concerns. Maxwell's (1995) research on women involved in American pro-life direct action revealed that some women became pro-life activists as a means of coping with miscarriage. In a Canadian study on the experience of mothers of children diagnosed as having Attention Deficit Hyperactivity Disorder, Malacrida (2001) argued that some mothers challenge efforts to label their child. The activism of the mothers is a brief, albeit important component of an article more specifically focused on the way that mothers experience the labeling of their children.

Holst-Warhaft's focus on grief as a catalyst for political activism is insightful and carries us forward, yet we need to keep in mind that family activism is not always inspired by grief. Indeed, for many of the family activists discussed in this paper, grief played a role in their path toward activism. But for some activists, their grief is wedded with a sense of injustice (that the death was preventable and/or that the system is not protecting individuals) that led them to activism. For others, their grief is wedded with a hope for change (e.g. a cure for cancer). Also, some families act to address current realities in their family, not tragic death, such as those who support research on treatments or cures of chronic disease or those who lobby for viable programs for special needs children and adults. Consistent with the Save the Smarties campaign, it was parents who launched the 'trans fat-free' consumer protest. They harnessed the purchasing power of parents to force producers of packaged food to remove hydrogenated oils (i.e., trans fats) that have been identified as a major contributor to heart disease. In a short period of time, many of the 
major producers of cookies (e.g. Christie, Voortman's) and crackers (e.g. Pepperidge Farm, Kraft) began to market so-called 'trans fat free' products. Trans fats pose no immediate risks for consumers, but it is well known that they contribute to the degeneration of the circulation system. Thus, here is an example of a type of parentactivism not rooted in tragic death, but a broader-based concern that affects all of us, not just the activists' children.

The fact that we see people finding ways to affect change around an issue that impacted them suggests something about how people think about themselves as social actors, and it says something about our social system, a system which perhaps calls upon us, perhaps allows us to have an influence on the social. Clearly family activists move well beyond personal pursuits, and seem to be guided by a sense of the common good or our collective responsibility to promote a safer, more humane, more predictable society.

\section{Family Activism and Remembrance}

Commemoration is often an integral aspect of family-based activism, and this is evident when activism follows tragic death. For example, families of victims of tragic death erect monuments, build memorial parks, hold annual memorial services, or establish memorial scholarships. These commemorative practices are orchestrated by families, often in conjunction with community groups and supporters. In some cases, the commemorative practices are conducted by non-family groups. A case in point is the annual Montreal Massacre ceremonies held by women's groups, schools, and university-based groups across the country. As noted above, the federal government assigned the date December 6th, the date the fourteen women were murdered in Montreal, to be the National Day of Remembrance and Action on Violence Against Women. What is captured so well in this title is that commemoration and action are linked. This linkage appears so often in the cases in my data base that I explored the social memory literature. Although only some cases of family-based social activism stem from tragic death, there are enough of them to warrant consideration of the ways that the social memory literature might serve to make sense of these types of family-based activism.

In the social memory literature, "remembrance" is conceptualized as both a "practice" (e.g. Halbwachs, 1992; Irwin-Zareka, 1994: Simon, 2005) and a "process" (Gregory \& Lewis, 1988). When an event occurs, people engage practices that will influence how the event is remembered, and these practices may change over time. As one aspect of remembrance, commemoration too is conceptualized as an action and a process. Commemoration is a routine aspect of death, and indeed commemoration rituals are built into the fabric of family life, with the means of commemoration largely routinized. Wakes, memorials, and funeral services are commemorative practices, as are family storytelling and the passing on of family heirlooms. Acceptance and closure are built into 
remembrance strategies. Commemorative practices are intended to create "closure" or "acceptance" that the person has passed on. Indeed, some of the family activists I have interviewed have experienced some pressure that they ought to "move on". Even "moving on" is culturally defined. For example, different cultures hold very different expectations for widows, and most cultures have norms about the extent to which the deceased person can mentioned. To a greater or lesser degree, the norm in many cultures is that, after a certain period of time, the deceased person is to be remembered primarily in the private thoughts and memories of family, friends, and community.

Acceptance and closure - moving on - is the last thing on the mind of family activists. They strive, rather, for public remembrance of the death because they believe the death was unjust or preventable. Their commemorative strategies are public, not private, and ostensibly policy-oriented. Consider the following statement drawn from a website established by a family-based activist, the mother of an adult child whose death was related to the controversial pain killer OxyContin. She writes simply that lessons from her daughter's death should be used to help anyone who becomes involved with OxyContin:

I am simply a Mom who wants to use this website as a means of communicating to families who have been affected by OxyContin that you are entitled to answers. You can call your Attorney Generals in your respective states and ask questions and are entitled to answers. You can call your Board of Medical Examiners in your state and ask for information regarding the physician who may have prescribed the drug. You need not sit back and accept the death or addiction of a loved one. There are recourses to be taken.

This site is dedicated in memory of my daughter, Jill Carol Skolek. She was born on February 26, 1973. She was killed on April 29, 2002 because she had the misfortune of being prescribed OxyContin. This site is also dedicated to all the families who have experienced devastation either through death or addiction of a loved one from OxyContin. This site has nothing to do with grieving. It has to do with justice. (http://www.oxydeaths.com/)

Jill Skolek's mother's statement is making a call to action, a call justified by a perceived injustice. Although the website is dedicated to her daughter, Jill's mother is careful to tell us that "This site has nothing to do with grieving. It has to do with justice."

Like many of the families described in this paper, this mother explicitly wants to share the preventable, tragic loss of her loved one. And like other family activists, her commemorative practices involve naming the cause of the tragedy as the focal point of remembrance. Simon and Rosenberg (2005: 68-69) call this practice emblemization to show how isolated act can be taken to symbolize all similar acts. Emblemization is "the 
practice of choosing/producing a specific act as standing for a range of other acts that are understood to be constituted on similar terms. As a family of resemblances, these acts are assumed to share certain characteristics, and the remembrance of one, hence, gestures to the remembrance of all." Simon and Rosenberg suggest that the Montreal Massacre is emblematic of male violence against women. To review some examples cited in this paper, Jill Carol Skolek's death is taken to be emblematic of OxyContin addiction, Peter Crompton's death is taken to be emblematic of risk-taking and drinking and boating, Yancy Meyer's death is taken to be emblematic of the cycle of family violence, and baby Halliday's death is taken to be emblematic of bed-sharing with infants.

My research suggests that emblemization can be expressed in single simple gestures or through more formal, collective efforts. When one draws attention to a cause of death deemed preventable, one emblemizes that tragedy. A single simple gesture could simply be asking for donations in lieu of flowers following the death of a loved one. Many families ask that donations be made to a specific charity, often an organization that addresses the cause of death, such as Canadian Cancer Association or The Heart and Stroke Foundation. A review of obituaries published in the Chronicle Herald for one week in 2005 (the week chosen at random) reveals that more than half of the families publishing death announcements asked that donations be made to a specific cause; most families asked for donations to health research institute. Emblemization also occurs when families establish a memorial bursary or scholarship or when they make a one-time or on-going donation to a specific organization. If we refer to examples given in this paper, Peter Crompton's family established the annual Peter Crompton SnowSmart Legacy Fund, which funds SnowSmart, a Canadian organization that educates youth about smart winter risk-taking, and Yancy Meyers' family established a bursary at the university Yancy attended. Like these families, many family activists seek out organizations that address the issue that touched their family, and encourage others to support the organization. In sum, the practice of emblemization helps families to focus public attention on particular social or health issue and direct resources to those organizations trying to bring about practical solutions, variously defined.

Through emblemization family members become "memory practitioners" who create or join a community of memory. A community of memory is created by the memory which draws memory practitioners together (Irwin-Zareka, 1994). For Simon and Eppert, these communities operate in very specific ways. "Communities of memory designate structured sets of relationships through which people engage representations of past events and put forth shared, complementary, or competing versions of what should be remembered and how."(2005: 61) Most importantly, tragic experiences seem to bring forth a sense of obligation to engage in the commemorative work. Simon and Eppert also suggest that being a witness to preventable tragedy produces a sense of obligation to act. Speaking on 
her activism following her son's murder, Louise Meyer expresses this sense of obligation when she says "It takes tragedy to bring people together and tragedy to make people move. When it happens to you, you feel compelled to do something”.

The strategies employed by family-based social activists also constitute what Simon (2005: 88) terms transactive memory. A transactive memory involves sharing a personal story with the purpose of transforming how other's understand the world. According to Simon, a transactive memory creates the possibility of a connection between victims and strangers, and that its power lies in a special kind of kinship; "public memory invokes a "kinship" beyond that rendered by biology, tribal traditions, or national histories" (Simon, 2005: 89). It is for this reason that transactive memory has a "potential radical pedagogical authority"(Simon, 2005: 89). He suggests that our shared sense of kinship has the potential to leads non-victims to join the community of memory created by witnesses, in this case, family members. It suggests that when families share their personal stories, they seek an empathic involvement in transforming the world.

As noted above, many of the larger family-based social change organizations seek membership from the broader community. This is reflected in the title of some organizations, such as Parents and Friends of Lesbians and Gays (PFLAG) and Family and Friends of Schizophrenics. As defined by Simon, transactive memory may be the mechanism which helps family members to compel non-family to join family-based social change organizations. And herein lies their capacity can grow and work to shape attitudes and policy. The PFLAG website indicates that this American family-based social change organization has a national board of directors, 13 regional directors, over 500 affiliates and more than 200,000 members and supporters. The website presents a summary of the policies the organization is working to influence, such as inclusion legislation, hate crime legislation, equality in the workplace, safe and welcoming schools, same-gender marriages, and adolescent sexual health, among others. Creating a community of memory beyond the families of victims empowers family activists to extend their influence in the community and the broader society.

\section{Conclusion}

This paper is intended to draw attention to family-based social activism. I argue that many individual actions and organized activities constitute activism, in that the family activist engages in practices explicitly aimed at raising awareness or bring about policy reform on an issue that affects or has affected that person's family. Clearly, many family activists are involved in a moral crusade, believing fully that the devastation and loss of life experienced by their family member could have been prevented. Many family activists become involved because their family experiences led them to see the need for change. This is no less true for parents advocating for resources for children with special needs 
than it is for the soccer mom advocating for healthy practices. Some family members have small-scale intermittent involvement in their activist pursuits; others are compelled to make a long-standing commitment to activism. I contend that family-based activism is commonplace.

Regardless of whether we call these commonplace activities activism or something else, we must accept that these activities challenge family sociologists to assess their theoretical and practical relevance for the constitution of society. Indeed, I would suggest that the activism describe in this paper is only one type of activity that families do to influence social life outside the boundaries of the home. We stand to learn a great deal by studying the work that families do beyond the narrow boundaries which have been drawn by family sociologists. Measuring influence is always difficult; measuring the influence of more or less organized and not primarily political actors can be hardly the exception to this rule. This study strongly suggests that sociologists studying families must go further to include the public roles family members play in society. Giving consideration to social memory literature to inform this process would be a step in the right direction. The main lesson to learn here is that students of social movements and social change must begin to consider families as significant agents of change. 


\section{REFERENCES}

Boss, P. 1993. Sourcebook of Family Theories and Methods: A Conceptual Approach. New York: Plenum Press.

Burr, W. 1979. Contemporary Theories about the Family. New York: Free Press.

Bussell, H. \& D. Forbes. 2001. "Understanding the Volunteer Market: The What, Where, Who and Why of Volunteering." International Journal of Nonprofit and Voluntary Sector Marketing, Vol. 7, No. 3, pp. 244-256.

Cheal, D. 1991. Family and the State of Theory. Toronto: University of Toronto Press.

Curtis, J.E., Baer, D.E. \& E.G. Grabb. 2001. "Nations of Joiners: Explaining Voluntary Association Membership in Democratic Societies." American Sociological Review, Vol. 66, No. 6, pp. 783-801.

Elshtain, J.B. 1982. The Family in Political Thought. Amherst: University of Massachusetts Press.

Galbraith, J.K. 1983. The Anatomy of Power. Boston: Houghton Mifflin Co.

Gregory, S.W. Jr. \& J.M. Lewis. 1988. "Symbols of Collective Memory: The Social Process of Memorializing.” Symbolic Interactionism, Vol. 35, pp. 213233.

Halbwachs, M. 1992. On Collective Memory. Chicago: University of Chicago Press. (Original work published 1941).

Holst-Warhaft, G. 2000. The Cue for Passion: Grief and Its Political Uses. Harvard University Press.

Ingoldsby, B., Smith, S. and E. Miller. 2004. Exploring Family Theories. Los Angeles: Roxbury Pub.

Irwin-Zarecka, I. 1994. Frames of Remembrance: The Dynamics of Collective Memory. London: Transaction Publishers.

LaCapra, D. 1998. History and Memory after Auschwitz. Ithaca, NY: Cornell University Press. 
Linenthal, E.T. 2001. Preserving Memory: The Struggle to Create America's Holocaust Museum. Oxford: Oxford University Press.

Malacrida, C. 2001. "Motherhood, Resistance, and Attention Deficit Disorder: Strategies and Limits." Canadian Review of Sociology and Anthropology, Vol. 38, No. 2, pp. 141-165.

Maroney, H.J. and M. Luxton. 1997. "Canadian Feminist Political Economy." In Understanding Canada: Building on the New Canadian Political Economy. Wallace Clement (ed.). Montreal: McGill-Queens, pp. 141-165.

Maxwell, C. 1995. "Coping with Bereavement: Real Grief, Imagined Death, and Pseudo-mourning among Pro-life Direct Activists." Ethos, Vol. 23, No. 4, pp. 437-452.

McCarthy, J.D. \& B. Edwards. 2004. "Strategy Matters: The Contingent Value of Social Capital in the Survival of Local Social Movement Organizations." Social Forces, Vol. 83, No. 2, pp. 621-651.

Roper, J. 2002. "Government, Corporate or Social Power? The Internet as a Tool in the Struggle for Dominance in Public Policy." Journal of Public Affairs, Vol. 2, No. 3, pp. 113-124.

Rotolo, T. 1999. “Trends in Voluntary Association Participation.” Nonprofit and Voluntary Sector Quarterly, Vol. 28, pp. 199-212.

Schwartz, B. 1982. "The Social Context of Commemoration: A Study in Collective Memory." Social Forces, Vol. 61, pp. 374-396.

Simon, R.I. 2005. The Touch of the Past: Remembrance, Learning, and Ethics. New York: Palgrave Macmillan.

Simon, R.I. with C. Eppert. 2005. Remembering Obligation: Witnessing Testimonies of Historical Trauma. In The Touch of the Past: Remembrance, Learning, and Ethics. R.I. Simon (ed.). New York: Palgrave Macmillan, pp. 50-64.

Simon, R.I. with S. Rosenberg. 2005. Beyond the Logic of Emblemization: Remembering and Learning from the Montreal Massacre. In The Touch of the Past: Remembrance, Learning, and Ethics. R.I. Simon (ed.). New York: Palgrave Macmillan, pp. 65-86. 
Snow, D.A., Soule, S.A. \& H. Kriesi. 2004 The Blackwell Companion to Social Movements. Malden, Mass.: Blackwell.

Sprey, J. 1990. Fashioning Family Theory: New Approaches. Newbury Park, California: Sage.

Today's Parent. 1994. "Moms and Dads making a Difference: Parents as Advocates, for other Families as well as their own." Today's Parent Magazine, Vol. 1, No. 7, pp. 54-58.

Verberg, N. and C. Davis (2004). "Transformative Commemoration: A Case Study of the Memory Activism of the Westray Families Group." Presented at the 2nd National Conference of the Canadian Society of Criminology, York University.

Warf, B. and J. Grimes. 1997. "Counterhegemonic Discourses and the Internet." Geographical Review, Vol. 8, No. 2, pp. 259-274.

White, J. \& D.M. Klein. 2002. Family Theories. Newbury Park: Sage. 